\title{
The Economic Consequences and Strategies of the US-China Trade War on Indonesia: A GTAP Simulation Analysis
}

\author{
Muhammad Rizal Taufikurahman \\ Study Program of Agribusiness \\ Trilogi University \\ Jakarta, Indonesia \\ mrizalt@trilogi.ac.id
}

\author{
Ahmad Heri Firdaus \\ Study Program of Management \\ Kwik Kian Gie School of Business \\ Jakarta, Indonesia \\ heri.ipb@gmail.com
}

\begin{abstract}
At present, the world economy is in uncertainty. One reason is that two economically large countries, the United States (US) and China are in conflict and beat the drums of trade war. This is indicated by the policy of US applying tariffs on a number of Chinese products, and then responded very quickly by China by implementing a reply tariff. The aim of this study is to analyze the economic consequences of the USChina trade war for Indonesia and Indonesia's strategies to respond to the trade war. The analytical method used is the Global Trade Analysis Project (GTAP) model. The results of the analysis show that the consequences of the US-China trade war on the found that trade wars between the US and China had an impact on the decline in the total output of goods produced by the US and China by $3.91 \%$ and $2.67 \%$ respectively. But the economic growth (PDB) of the US and China will be corrected by $0.08 \%$ and $0.66 \%$ respectively. Exports are still affected by $\mathbf{- 0 . 2 4 \%}$ with greater implications. It means Indonesia has not been able to take advantage of the situation as a source of economic growth (GDP) projected to only increase by $0.01 \%$. This means that Indonesia also needs to improve, so that investment in the real sector continues to flow profusely even though the China-US trade war has not been completed. The recommendation suggested that in the short-term strategies that need to be done are increasing export competitiveness, encouraging export-oriented industrial productivity, expanding and strengthening domestic and world markets, and controlling the amount of imports. In the longterm strategies include the need to improve the quality of human resources in the trade and industry sectors, utilization of the results of research and development, and infrastructure development is right on target for increased productivity.
\end{abstract}

Keywords-economic impacts, strategies, US-China trade war, GTAP analysis

\section{INTRODUCTION}

Indonesia's economic journey for almost a year has been tinged with challenges that are not easy. The rupiah exchange rate which tends to be stable in 2017 has actually weakened since February 2018. Even the depreciation of the Rupiah translates into IDR 15,000 per $\$$ US when it entered the beginning of October 2018. Even though the assumption of the Rupiah exchange rate in the 2018 State Budget is set at IDR 13,400 per USD (INDEF, 2018). Fundamental factors in the form of a widening current account deficit combined with an increase in global economic uncertainty due to the aggressiveness of the normalization of the US (US) benchmark interest rate and trade wars were accused of being the main cause of the weakening Rupiah.

In general, the realization of economic growth in several countries in 2019 amid conditions in the United States (US) trade war in China is still unable to meet the 2019 target (INDEF, 2018). Data on the realization of economic growth from Bank Indonesia (2019) shows that only the US, UK, China are growing above target. Italy is still growing negatively, while China has the highest growth of 6.4 percent (yoy). India's growth is only 5.8 percent (yoy) in 2019 and is still far from the target of 7.3 percent in 2019.

The US-China tariff trade war is a symptom of many more fundamental issues. It is part of the rise of protectionism and nationalism that led to Brexit, and the election of many political leaders, such as President Trump (Pangestu, 2019). Furthermore, Pangestu (2019) explains one of the underlying reasons because historically a number of US imports from Indonesia are goods who are not subject to a rate increase.

This condition allows Indonesia to be prepared for the escalation of the escalation of the US China trade war. Even though the domestic economy is dominated by private household consumption, this does not necessarily make Indonesia sufficiently defensive against the trade turmoil that has occurred. The government still needs to prepare various strategies and 'ammunition' to manage the economy amid the phenomenon of this trade war.

This paper has the economic consequences and the consequences of US-China trade war on Indonesia economic performance. The potential impact of the proposed tariff increases is calculated using Global Trade Analysis Project (GTAP) analysis. Capital deepening and technological spill over induced by account to explore the long-run influence. We can deliver the following implications for macroeconomic indicators such as output aggregate, product domestic bruto, investment, export and import performance.

\section{Previous Studies}

Previous studies on the US-China trade conflict in 2018 relied on a scenario analysis, due to the ambiguity in policy decisions and implementation. The International Monetary 
Fund (IMF, 2018) demonstrated four consecutive scenarios in the US-China trade conflict and its spillover effects on the world economy. The first two scenarios are based on announced tariff increases by the US and China, the third scenario includes imaginary additional tariff increases on automobile imports, and the forth scenario includes negative shocks on the markets or investor sentiment in general. The first two realistic scenarios indicate that the GDP in the US and emerging Asian economies, including China, would fall by $0.2 \%$ in the first year, while the GDP in Japan and EU would increase slightly.

Similar to the IMF's simulation, Kobayashi and Hirono (2018b) ran a macroeconomic model to simulate the potential impact of $10 \%$ or $25 \%$ tariff increases on the GDP, with two different fiscal response assumptions - revenue neutral and revenue surplus. The GDP in the US falls by $0.00-0.15 \%$ in the $10 \%$ increase scenario and by $0.00-0.28 \%$ in the $25 \%$ increase scenario. $\mathrm{Li}, \mathrm{He}$, and $\mathrm{Lin}$ (2018) calibrated their original CGE model to calculate welfare changes caused by tariff increases by the US and China. Their model has 29 countries/regions with tradable and nontradable goods and 2013 as the benchmark year. When respective tariffs on imports between the US and China are increased by $15 \%$, the GDP in the US increases by $0.007 \%$ while in China, it falls by $0.667 \%$. In the scenario where respective tariffs on imports are increased by $30 \%$, again, the GDP in the US increases by $0.037 \%$ while in China, it falls by $1.152 \%$.

The trade war will lead to a decrease in China's GDP, but potential reallocation may benefit some ASEAN countries, notably Vietnam. However, the reallocation impact on Indonesia is negligible. Abiad et al. (2018), for example, uses Multiregional Input Output Tables to look for the impact of trade war on Asian countries.

Bollen and Rojas-Romagosa (2018) demonstrated seven scenario simulations using the WorldScan CGE model developed by the Netherlands Bureau for Economic Policy Analysis. One of the seven scenarios includes the US-China tariff increases. According to their results, the GDP in the US and China falls by $0.1 \%$ and $1.4 \%$, respectively, due to tariff increases. Note that their simulation only considers the tariff increases in July 2018 and does not take into account the additional measures announced in September.

Tsutsumi (2018) examined the economic consequences of trade measures taken by both the US and China and confirmed that tariff increases would negatively affect both economies. The effect of China's retaliatory measures and their effect, including capital deepening and trade induced technological changes. The GDP in the US falls by $0.00 \%$ points or $0.24 \%$ points, while the GDP in China falls by $0.11 \%$ points or $0.88 \%$ points. The equivalent variation in the US worsens by $11.4-40.4$ billion USD, while in China it worsens by 3.6-55.9 billion USD.

At first glance, the retaliation induces losses of 11.4 billion USD in the US at the cost of 3.6 billion USD loss in China. Although this is not a welfare enhancing case as $\mathrm{Li}$ et.al. (2018) argue, it does seem to be a cost -effective measure according to the relative changes in equivalent variations. Having said that, one would find that another long-run simulation would show different results. The retaliation not only decreases the US GDP by $0.24 \%$ and equivalent variations by 40.4 billion USD, but it also decreases the Chinese GDP by $0.88 \%$ and equivalent variations by 55.9 billion USD. Eventually, China will lose more than the US.

\section{METHODOLOGY}

\section{A. Data}

The research data used is the GTAP data version 9.0. This is the same data set used in the three previous studiesRosyadi and Widodo (2018), Bollen and Rojas-Romagosa (2018), and Tsutsumi (2018). The benchmark year varies by data series, but the national accounts data and trade statistics are adjusted to replicate the balance among regions. The original database consists of 140 countries/ regions and 57 commodities/industries. For analytical purposes, the GTAP data is aggregated into 18 countries/ regions and 30 commodities/industries.

\section{B. Model}

The basic concept of GTAP as an analysis used in this study refers to Oktaviani (2008). The GTAP model and the CGE model are models that share the basic concepts of expenditure and purchasing among economic actors. The two models are structural models built on the basis of microeconomic theories, where behaviors in each economic agent (behavioral parameters) are explained in detail.

The model used in this study is the GTAP model version 6.2, with an additional equation to link trade openness and technological changes. The following section briefly explains the basic structure of the model. In the model, there is a social welfare function composed of private consumption, government consumption, and national savings. Since the function takes the form of Cobb-Douglas, each share is held constant. Each commodity demand of private consumption is driven by income, relative prices, and initial quantity of demand. Domestic demand is comprised of domestic supply and aggregate imports, which are elastic to relative price changes. For the purposes of this study, the differences between economic activities in the el GTAP mode will be explained. Government intervention and trade are the main focus that will be discussed in the model. The images presented are the flow of value (money) in the economy and not a real flow (flow of goods), where the relationship between the two flows is opposite (Oktaviani, 2008).

\section{Simulation scenario}

The economic impact of the US and China's tariff increases on Indonesia is calculated using different macroeconomic closures to analyze the three causes of changes. The effective additional tariff rates in China are uneven by commodity, reflecting a difference in the first and second round of retaliation. This section will analyze the effects of trade wars of the US-China on Indonesia's investment and export performance as well as several other developing countries in the Asian region. The consequences of the trade war will be analyzed by the Global Trade Analysis Project Model (GTAP) version 9.0.

After establishing sector aggregation, the next step is to determine the amount of shock to products that have been affected by rising import tariffs by the US and China. In the 
table below, there are some products that are subject to US import tariff increases against China and vice versa. The range of tariff increases proposed by the two countries is quite diverse, ranging from 0.1 percent to 47.43 percent. In the GTAP analysis, the magnitude of the shock will be used as a scenario for simulation of trade war between the US and China. As noted in the previous section, an ad hoc equation is incorporated to capture the trade induced technological change on the whole economy. The value of tariff percentage as value for simulation scenario shock by commodities/industries in this study can be seen in Table I.

TABLE I. VALUE OF TARIFF AS SHOCK SiMULATION

\begin{tabular}{|l|r|r|}
\hline \multirow{2}{*}{ Commodities/Industries } & \multicolumn{2}{c|}{ Tariff (\%) } \\
\cline { 2 - 3 } & \multicolumn{1}{|c|}{ US } & \multicolumn{1}{c|}{ China } \\
\hline Vegetable oils and fats & 0.10 & 2.40 \\
\hline Dairy products & 5.94 & 31.29 \\
\hline Processed rice & 4.36 & 26.00 \\
\hline Food products nec & 2.76 & 35.82 \\
\hline Beverages and tobacco products & 4.10 & 31.06 \\
\hline Petroleum, coal products & 25.17 & 3.87 \\
\hline Chemical, rubber, plastic prods & 27.75 & 6.05 \\
\hline Ferrous metals & 26.03 & 2.29 \\
\hline Metal products & 13.19 & 0.95 \\
\hline Motor vehicles and parts & 25.86 & 47.43 \\
\hline Transport equipment nec & 28.43 & 2.55 \\
\hline Electronic equipment & 25.25 & 0.72 \\
\hline Machinery and equipment nec & 26.47 & 4.83 \\
\hline Manufactures nec & 7.57 & 14.48 \\
\hline
\end{tabular}

Source: Some Literature, 2019 (calculated)

\section{RESULTS AND DISCUSSION}

The US and Chinese economies play a big role in the world. The contribution of US GDP to the world economy in 2017 reached $24.03 \%$, while China recorded a portion of $15.2 \%$. On the other hand, the role of Indonesia's GDP has only reached $1.25 \%$ of world GDP. In addition to the large role in world GDP, the role of trade value flows from the US and China also dominates. The export contribution of the US and China in the world reached $8.8 \%$ and 12.8 percent. On the other hand, the US took $13.5 \%$ of world imports, while China accounted for $10.3 \%$. This condition is clearly very different when compared to Indonesia and various other developing countries. With the magnitude of the economic power of the US and China in the world, the influence of the two countries' policies on the world economy is also great. This is shown in Table II.

TABLE II. THE ROLE ECONOMY OF US, CHINA AND INDONESIA IN THE WOLD

\begin{tabular}{|l|r|r|r|}
\hline \multicolumn{1}{|c|}{ Indicators } & \multicolumn{1}{c|}{ US } & \multicolumn{1}{c|}{ China } & \multicolumn{1}{c|}{ Indonesia } \\
\hline GDP 2017 (bil \$US) & 19390.60 & 12237.70 & 1015.50 \\
\hline Share on World GDP & 0.24 & 0.152 & 0.013 \\
\hline Export 2017 (bil \$US) & 1546.30 & 2263.40 & 168.80 \\
\hline Share on World Exports & 0.088 & 0.128 & 0.009 \\
\hline Import 2017 (bill \$US) & 2408.5 & 1843.80 & 157.40 \\
\hline Share on World Imports & 0.145 & 0.103 & 0.018 \\
\hline Trade Balance 2017(bill\$US) & -862.20 & 419.50 & 11.40 \\
\hline
\end{tabular}

\section{A. The Consequences of the US-China Trade War}

Based on the data above, that the role of the US and China's economies and by looking at the role of the two countries in Indonesia's exports, trade wars can certainly have a direct influence on the world economy. This section will present a simulation of the impact of trade war on the economy of Indonesia and several other countries. A trade war is assumed as a policy of implementing import tariffs on some products involved in the US-China trade war. The impacts on macroeconomic indicator performance such as output aggregat, product domestic bruto (PDB), investment, export and import.

The economic role of the US and China and by looking at the role of the two countries in Indonesia's exports, a trade war can certainly have a direct influence on the world economy. This section will present a simulation of the impact of trade war on the economy of Indonesia and several other countries. A trade war is assumed as a policy of implementing import tariffs on some products involved in US and China trade. Some Chinese products that are subject to tariffs by the US include steel and aluminum; electrical engine products and their components; automotive products and electronic products.

The results of simulations conducted, it was found that trade wars between the US and China had an impact on the decline in the total output of goods produced by the US and China by $3.91 \%$ and $2.67 \%$ respectively. This is because in the short term exports of both countries have decreased due to the policy of the tariff war. This finding is in line with the findings (Matsuhiko, 2018) that the GDP in the US and China drops while other countries and regions slightly gain through trade diversion effects because of drop the total output.

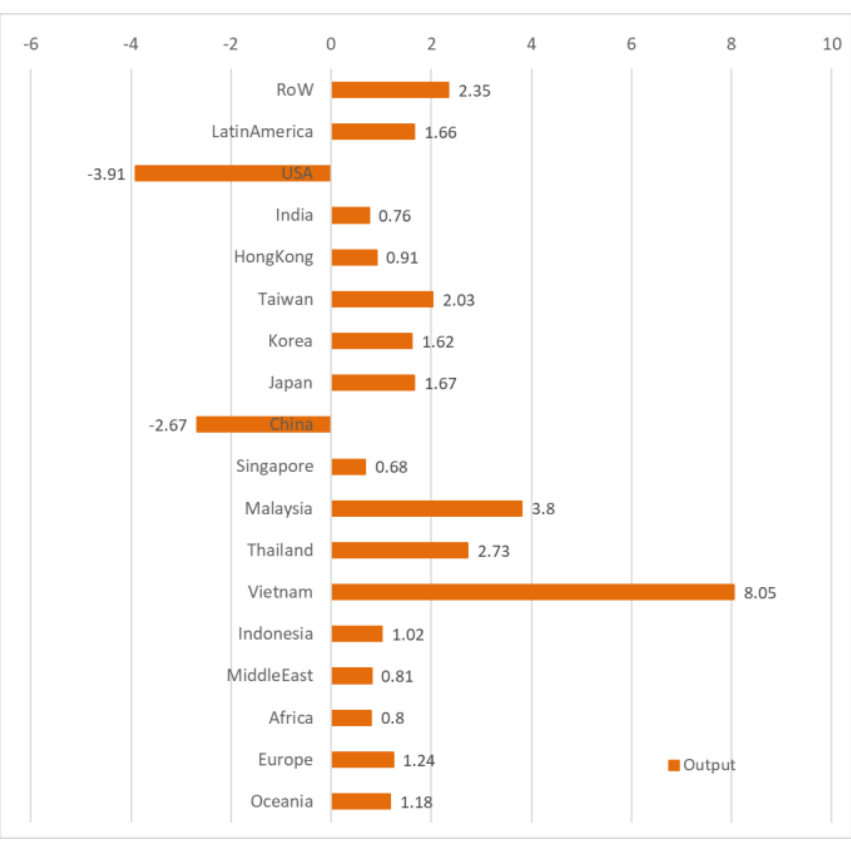

Fig. 1. The Consequences of the US-China Trade War on the Output

On the other hand, the amount of output produced by other countries such as Japan, Malaysia, Thailand, Vietnam and Indonesia has increased. Malaysia has relatively large profits compared to other countries. The number of Vietname's output is estimated to have the highest increase compared to other countries, namely an increase of $8.3 \%$. Similarly, Malaysia, Thailand and Taiwan will experience it 
the increase in the number of output is $3.8 \%, 2.73 \%$ and $2.03 \%$. While the increase in total output for goods production experienced by Indonesia is relatively lower, reaching only $1.02 \%$. This shows that Indonesia still has not prepared more competitive production, especially from the technological aspects and production costs in world trade. This shows in Figure 1.

Increased GDP in Vietnam, Malaysia and Thailand indicates that the country is better prepared to anticipate the effects of trade war. The export market diversification that has been carried out by Malaysia and Thailand and closer trade relations with the US has made these two countries take positive momentum from the threat of trade war. Likewise, Vietnam, which has close trade relations with the US and China, is able to take momentum from the US and China tariff wars. Vietnam Exports to the US are predicted to increase along with trade barriers imposed by the US on China. Globally, the increase in the number of outputs will affect economic growth which is predicted to slow down. This is because more because of the corrected US and Chinese economy.

The policies of the US and China which decided to fare wars clearly hurt the two economic giants. Based on GTAP analysis, the economic growth of the US and China will be corrected by $0.08 \%$ and $0.66 \%$ respectively. This is partly due to the waning role of investment and exports in both countries. In more detail can be seen in Figure 2.

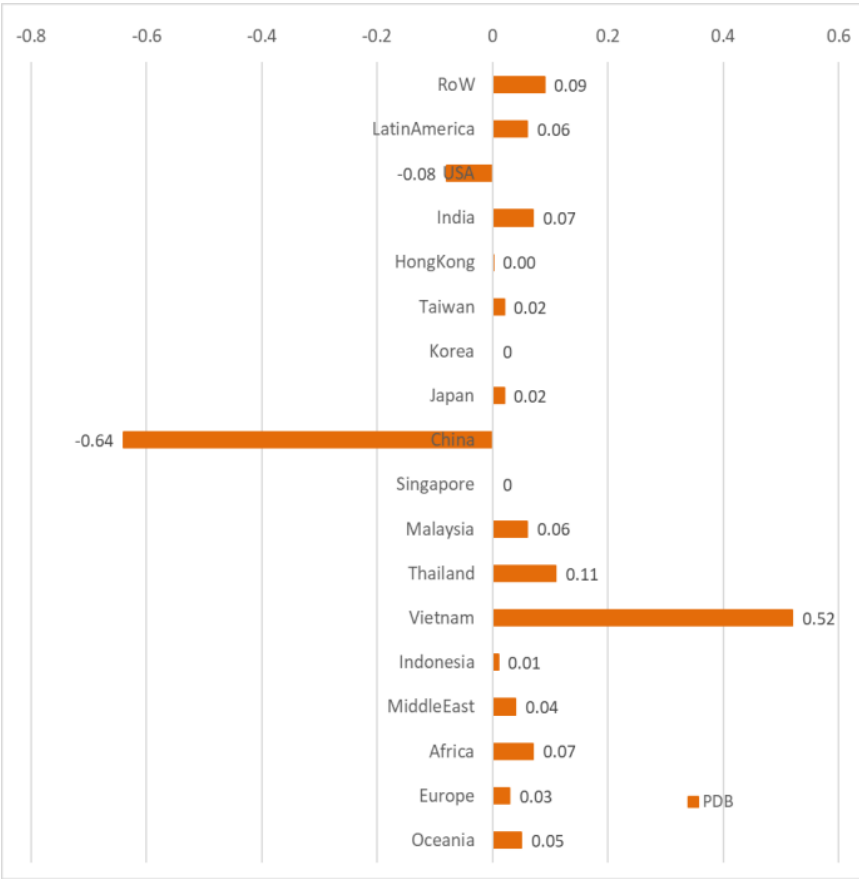

Fig. 2. The Consequences of the US-China Trade War on Product Domestic Bruto (PDB)

The consequences of US and Chinese trade wars in increasing aggregate output of goods production have boosted GDP in some countries. This positive relationship occurred in Vietnam, Malaysia and Thailand, including in Indonesia. It's just that Singapore doesn't benefit or lose. The largest increase in GDP was obtained by Vietnam, which increased by $0.52 \%$, followed by Thailand and Malaysia. Each of them is $0.11 \%$ and $0.06 \%$. Indonesia only grew $0.01 \%$ of GDP. This shows that Vietnam benefited greatly from this trade war. Likewise, Malaysia and Thailand. The positive impact Vietnam gained due to the agility of the Government of Vietnam through the Customs and Excise department was improving the identification method of transshipment and devising sanctions for violating companies. The same goes for the foreign ministry which has formed a steering committee to respond to the issue. However, in Indonesia it does not carry out this policy. Apart from the fact that aggregate output productivity is also very weak due to very low production of goods.

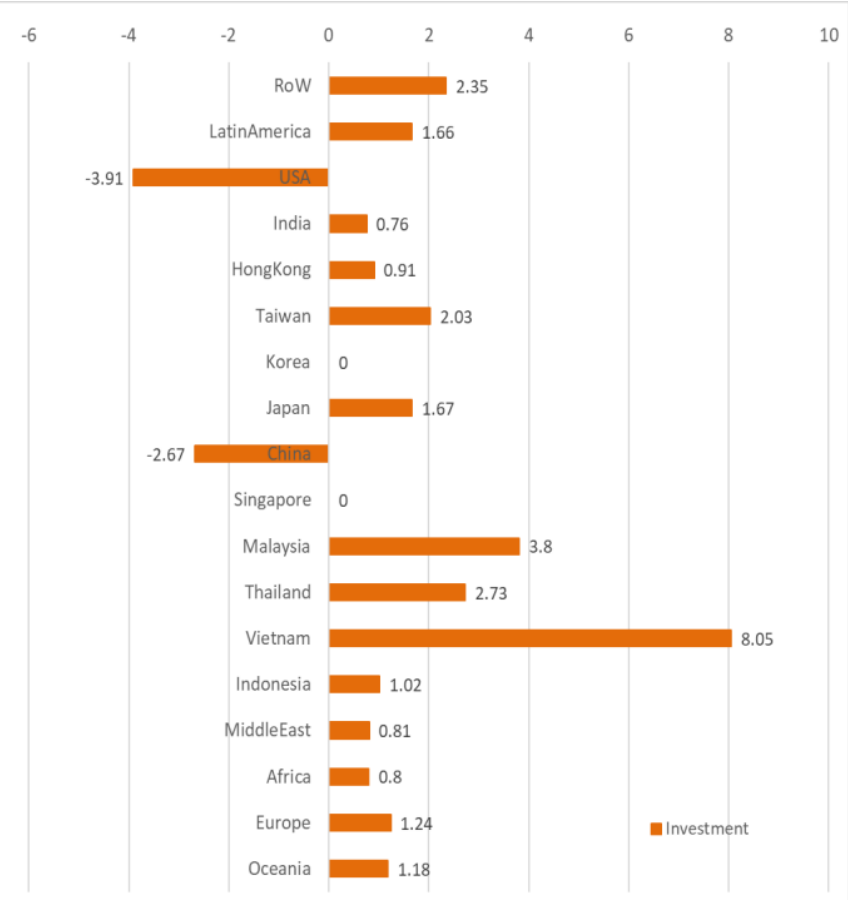

Fig. 3. The Consequences of the US-China Trade War on Investment

According to figure 3 , that the consequences of the US and China trade wars. It turns out that the GTAP simulation results obtained that the impact on investment, where US investment shrank $3.91 \%$ while in China fell $2.67 \%$. In addition, the significant impact felt by the US and China is the export performance. The increase in investment experienced by Vietnam, Thailand, Malaysia and Taiwan is able to be converted into export value.

It can be seen from the increase in exports in these countries. Vietnam's largest export increase was reached $2.58 \%$, then Malaysia $0.39 \%$, Taiwan $0.27 \%$ and Thailand $0.23 \%$. Even with Indonesia, India and even Japan, the increase in investment experienced by these countries has not been able to produce an increase in exports. For Indonesia, the problem with the structure and effectiveness of investment is thought to be the reason why investment is difficult to drive export performance.

The situation of US and Chinese trade wars also allegedly had a strong impact on the flow of trade in the world. In this regard, the GTAP simulation in this section will look at the extent to which trade wars affect the performance of Indonesia's exports and imports as well as several countries in Asia. Based on Figure 4. The action of repaying tariffs will have an impact on reducing US and Chinese exports and imports. The decline in China's exports and imports is higher than the US. 


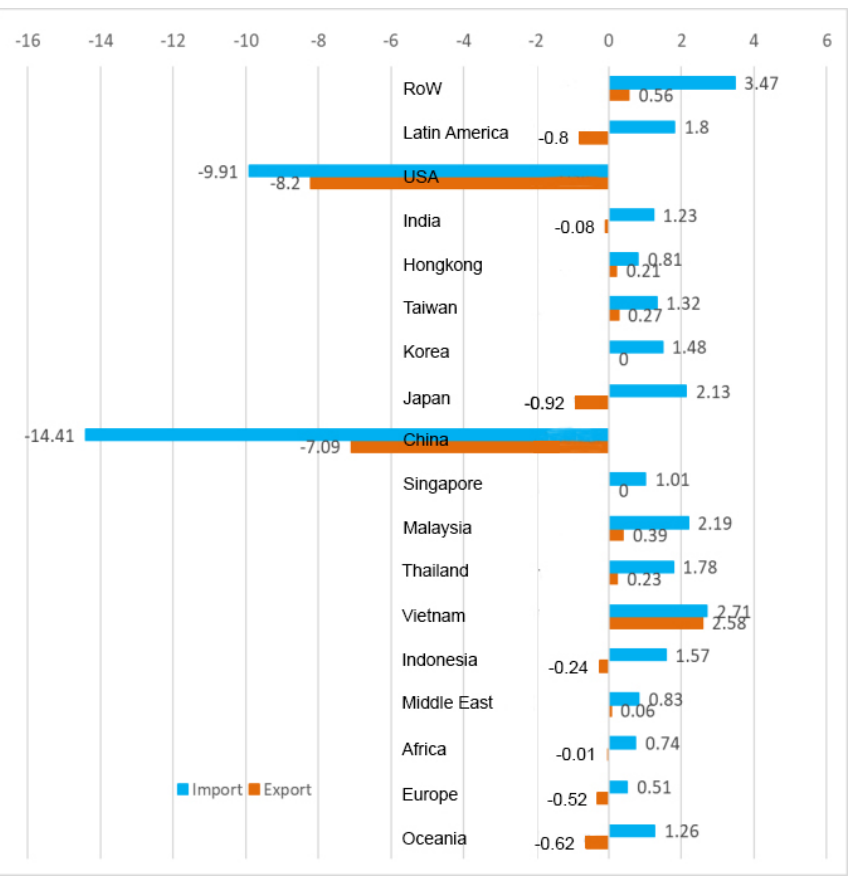

Fig. 4. The Consequences of the US-China Trade War on Export and Import Performance

The increase in exports experienced by Vietnam, Taiwan and Thailand was caused by an increase in exports to the US. When many countries (including Indonesia) experienced a decline in exports to the US, the three countries actually showed the opposite. Based on data obtained from the ITC, in 2019 in the first semester was increased the demand for US imports mostly from Vietnam, where the surge in imports increased to $39.5 \%$ (YoY). While US imports from Taiwan and Thailand also increased by $2.1 \%$ and $5.8 \%$. The opposite happened in Indonesia, where in 2019 first semester, there was a decline in imports from Indonesia by 3.25 percent (YoY). Based on data obtained from ITC, the increase in US imports from Vietnam, Taiwan and Thailand was mainly driven by a number of products, including electronics and equipment (HS 85) and electric engines and components (HS 84). As for Vietnam, a surge in demand for US imports of textile products, Vietnam's apparel and footwear contributed to the increase in the country's exports

\section{B. The Strategy Policy of the US-China Trade War on Indonesia}

The existence of the US-China trade war illustrates that the trade war should not be seen pessimistically as developing countries like Indonesia. The state must wear positive glasses by issuing various appropriate strategies to deal with it. Through policies to make this trade war a momentum to increase its national capacity to strengthen its position in global competition. The strategic policies that is immediately carried out divided become the short term and the long term.

The strategic policy will be carried out immediately this year in the short term is the expansion and strengthening of markets and import control; the import volume controlled policy; the improving the taxation system for domestic businesses to encourage the investment climate; the improving the investment climate through competition healthy business; and provision of fiscal facilities in accordance with investor needed. Furthermore, the strategies that must be carried out in the long term is improving the quality of human resources; the increasing research and development investment; and infrastructure development on the targeted for increased productivity.

\section{CONCLUSION AND RECOMMENDATION}

Indonesia is currently faced with an external situation in the US-China trade wars, where Indonesia is only an abundance of investment at a rate of $1.02 \%$, slightly better than India $0.76 \%$ and Hong Kong $0.91 \%$. The small investment turned out to be unable to convert into exports. As a result, exports are still affected by $-0.24 \%$ with greater implications. It means Indonesia has not been able to take advantage of the situation as a source of economic growth (GDP) projected to only increase by $0.01 \%$.

The expectation of a positive consequence is to attract foreign investment, at the ASEAN level, need to pay attention to interest rates, as well as growth in the value added of the manufacturing industry. While at the Asia Pacific level it is also necessary to pay attention to imports for manufacturing, especially raw materials. But specifically in Indonesia, declining levels of corruption will increase foreign trust to invest.

The suggest important considerations above need to be accompanied by important efforts to make investment increasingly. The recommendation suggested that in the short-term strategic policies is the expansion and strengthening of markets and import control; the import controlled policy; the improving the taxation system for domestic businesses to encourage the investment climate; the improving the investment climate through competition healthy business; and provision of fiscal facilities in accordance with investor needed. The strategy that must be carried out in the long term to anticipate the US-China trade war is improving the quality of human resources; the increasing research and development investment; and infrastructure development is right on target for increased productivity.

\section{ACKNOWLEDGMENT}

I would like to thanks for the director executive of Institute for Development of Economic and Finance (INDEF), who has given me the confidence to be one of the researchers in this study. Besides that, in accessing the latest GTAP database in answering the problem of this study. In addition, to Prof. Rina Oktaviani (RIP) and Dr. Dedi Budiman Hakim who has been tutor to teach many aspects about GTAP such as concepting, calculating, modeling, writing and inspiration for GTAP modeling development.

\section{REFERENCES}

[1] Abiad, A., Baris, K., Bernabe, J. A., Bertulfo, D. J., Camingue, S., Feliciano, P. N. \& MercerBlackman, V. (2018). The Impact of Trade Conflict on Developing Asia. Asian Development Bank Economics Working Paper Series, (566).

[2] Aguiar, A., Narayanan, B., \& McDougall, R. (2016). An Overview of the GTAP 9 Data Base. Journal of Global Economic Analysis, 1(1), 181-208. [doi:dx.doi.org/10.21642/JGEA.010103AF] 
[3] Amiti, M., S. J. Redding, and D. Weinstein. 2019. The Impact of the 2018 Trade War on US Prices and Welfare (No. W25672). National Bureau of Economic Research.

[4] Bollen, Johannes and Hugo Rojas -Romagosa (2018). Trade Wars: Economic impacts of US tariff increases and retaliations. An international perspective ", CPB Background Document , July 2018 [CPB-Background-Document -July2018-Trade-Wars-update.pdf]

[5] Bown, Chad P., Euijin Jung, and Zhiyao (Lucy) Lu (2018). Trump and China Formalize Tariffs on \$260 Billion of Imports and Look Ahead to Next Phase. September 20, 2018 [https://piie.com/blogs/trade-investment-policy-watch/trump-and china-formalize-tariffs-260billion-imports-and-look]

[6] Corong, E., Hertel, T., McDougall, R., Tsigas, M., \& van der Mensbrugghe, D. (2017). The Standard GTAP Model, Version 7. Journal of Global Economic Analysis, 2(1), 1-119. [doi: http://dx.doi.org/10.21642/JGEA.020101AF]

[7] INDEF. (2018). Adu Strategi di Tengah Perang Dagang. INDEF Press Jakarta.

[8] Gobal Trade Analysis Project. 2017. GTAPagg Database Aggregator. Purdue University.

[9] Hayakawa K, Matsuura T. (2017). FTA Use in Export-Platform FDI: Evidence from Export to China by Japanese Affiliates in ASEAN. Journal of Southeast Asian Economies, 14(2): 266-282.

[10] Morrison, Wayne M. (2018). China-U.S Trade Issues. CRS Report, Congressional Research Service. July 30, 2018. [https://fas.org/sgp/crs/row/RL33536.pdf]

[11] Oktaviani, R., dan E. Puspitawati. (2008). Teori, Model dan Aplikasi GTAP (Global Trade Analysis Project) Di Indonesia. Departemen Ilmu Ekonomi, Fakultas Ekonomi dan Manajemen, Institut Pertanian Bogor. IPB Press.

[12] Pangestu, M., \& Armstrong, S. (2018). Asian economic integration: The state of play. In Shiro Armstrong and Tom Westland (eds). Asian Economic Integration in an Era of Global Uncertainty (pp. 55-61). Canberra: ANU Press.
[13] Pengestu, Marie (2019). China-US Trade War: an Indonesian Perspective. Economic Journal, 12:2, 208-230. [doi: 10.1080/17538963.2019.1611084]

[14] Rizal, Y., and Pangestu, M. (2018). Who is afraid of economic globalisation? People's perception of globalisation in Indonesia. In Patunru, Pangestu and Basri. Indonesia in the New World: Globalisation, Nationalism and Sovereignty (pp. 109-130). Singapore: Institute for Southeast Asian Studies.

[15] Rosyadi, Saiful Alim, and Tri Widodo (2018). Impact of Donald Trump's tariff Increase Against Chinese Imports on Global Economy: Global Trade Analysis Project (GTAP) model. Journal of Chinese Economic and Business Studies, 16:2, 125-145, 2018. [doi:10.1080/14765284.2018.1427930]

[16] Schott, J. J., and E. Jung. (2019). In US-China Trade Disputes, the WTO Usually Sides with theUnited States. Peterson Institute of International Economics, March 12. [https://piie.com/blogs/tradeinvestment-policy-watch/us-china-trade-disputes-wto-usually-sidesunited-states]

[17] The American Chamber of Commerce in People's Republic of China (2019). China Business Survey Report. Beijing: The American Chamber of Commerce in People's Republic of China.

[18] The World Bank.(2019). Global Economic Prospects, January 2019: Darkening Skies. Washington, DC: World Bank: International Bank for Reconstruction and Development. Washington, DC. [https://www.worldbank.org/en/news/press-

release/2019/01/08/darkening-prospects-global-economy-to-slow-to29-percent-in-2019-as-trade-investment-weaken

[19] Tsutsumi, Matsuhiko. (2018). The Economic Consequences of the 2018 US-China Trade Conflict: A CGE Simulation Analysis. CIS Discussion Paper Series, No.672, Centre for Intergenerational Studies, Institute of Economic Research, Hitotsubashi University. [http://cisier.hitu.ac.jp/Common/pdf/dp/2018/dp672.pdf] 